\title{
Corrosion Behaviour of Zn-Al-Cu Alloy in HCI Solution and its Inhibition
}

\author{
M.M. Ahmed* \\ Chemistry Department, College for Girls, Ain Shams University, Cairo, Egypt
}

Received 8 June 2004; accepted in revised form 2 February 2006

\begin{abstract}
The corrosion behaviour of $\mathrm{Zn}-\mathrm{Al}-\mathrm{Cu}$ alloy was studied in pure $\mathrm{HCl}$ solutions and in the presence of different concentrations of inhibitors. The techniques of measurements were: weight loss, linear polarization, polarization impedance and corrosion penetration. It was found that the corrosion rate of this alloy is greatly higher than that of $\mathrm{Zn}$ or Al. The inhibitors used were: heterocyclic pyridine (p), 2-methyl pyridine (2 mp), 3-methyl pyridine $(3 \mathrm{mp}$ ) and 4-methyl pyridine (4 $\mathrm{mp}$ ). These inhibitors behave as mixed type and their inhibition efficiency increases according to the order: $2 \mathrm{mp}<3 \mathrm{mp}<\mathrm{p}<4 \mathrm{mp}$. The values of activation energy of corrosion were determined in pure acid and in the presence of inhibitors. It was found that the presence of these inhibitors increases the value of activation within the same order of their inhibitory effect. The adsorption of the investigated inhibitors on the surface of the alloy follows Frumkin's isotherm.
\end{abstract}

Keywords: corrosion, zinc alloy, heterocyclic pyridine, galvanostatic polarization, impedance.

\section{Introduction}

Zinc-aluminum alloys can be used for manufacturing fittings exposed to steam, sea-water, gears, bushings and other components subjected to friction. Also Al$\mathrm{Zn}, \mathrm{Zn}-\mathrm{Al}$ and $\mathrm{Zn}$ are used as coatings for the protection of steel. These coatings were subjected to many investigations to test their corrosion resistance in different media [1-12].

These corrosive media included mainly sea-water and $\mathrm{NaCl}$ solutions. Little attention was paid to the corrosion of these coatings in acid media.

Corrosion inhibitors protect these alloys and coatings from the destructive effect of the acids. Most acid corrosion inhibitors are heterocyclic compounds containing nitrogen, sulphur, and oxygen. Inhibition appears to result from the adsorption of molecules and ions at the metallic surface. Adsorption depends on the chemical structure of the inhibitors, the type of aggressive acid and on the

\footnotetext{
*Corresponding author. E-mail address: drsohairr@hotmail.com
} 
nature of the metal. Pyridine is a heterocyclic compound with one nitrogen atom forming part of six-membered ring.

In the present work the behaviour of $\mathrm{Zn}-\mathrm{Al}-\mathrm{Cu}$ alloy was investigated in $\mathrm{HCl}$ solution. Also, the corrosion of this alloy was inhibited by the action of pyridine and its derivatives.

\section{Experimental}

Experiments were performed with the alloy having the composition: $96.34 \% \mathrm{Zn}$, $2.8 \% \mathrm{Al}, 0.86 \% \mathrm{Cu}$. The corrosion rate of this alloy was determined by weight loss, linear polarization and galvanostatic polarization impedance, and corrosion penetration measurements. For weight loss measurements, the samples had the dimensions of $3 \times 3 \times 0.4 \mathrm{~cm}$. For the electrochemical measurements, electrodes measuring $2 \times 1 \times 0.4 \mathrm{~cm}$ were used. For electrical connection a stout copper wire lead was fixed at one end of the electrode by mechanical jamming. A platinum sheet of $1.5 \times 1.5 \mathrm{~cm}$ and a saturated calomel electrode (SCE) were used as an auxiliary and reference electrode, respectively. The current values used in electrochemical measurements were derived from a constant current unit $(2 \mu \mathrm{A}-200 \mathrm{~mA})$, LG Precision Co, Ltd, Korea. The potential of the working electrode relative to SCE was measured on digital multimeter (model 1008, Kyoritsu, Japan). Impedance measurements were carried out using impedance measurement system (IM6 Zahner Electric, Meßtechnik, Germany).

The organic additives used as inhibitors were: pyridine (p), 2- methylpyridine (2 $\mathrm{mp}$ ), 3- methyl pyridine (3 mp) and 4-methyl-pyridine (4 mp) ( Merk, Germany). These compounds have the structures:<smiles>c1ccncc1</smiles><smiles>Cc1ccccn1</smiles><smiles>Cc1cccnc1</smiles><smiles>Cc1ccncc1</smiles>

Prior to the measurements, the samples and electrodes were polished with emery paper up to 4/0, washed thoroughly with distilled water, rinsed in acetone and dried in air. The aggressive solutions were prepared by dilution of analytical grade $37 \% \mathrm{HCl}$ with doubly distilled water.

In weight loss measurements, the samples were weighed before and after each experiment. The weight loss was calculated and from it the rate of corrosion, $\mathrm{R}_{\mathrm{w}}$, $\left(\mathrm{mg} / \mathrm{cm}^{2} / \mathrm{h}\right)$ was calculated.

In linear polarization measurements, the values of polarization resistance, $R_{p}$, were determined from the slopes of plots of $E$ versus $i\left(R_{P}=\Delta E / \Delta i\right)$.

In galvanostatic polarization measurements, the values of corrosion current density, $i_{\text {corr }}$, were deduced from polarization curves by extrapolation of Tafel's lines. 


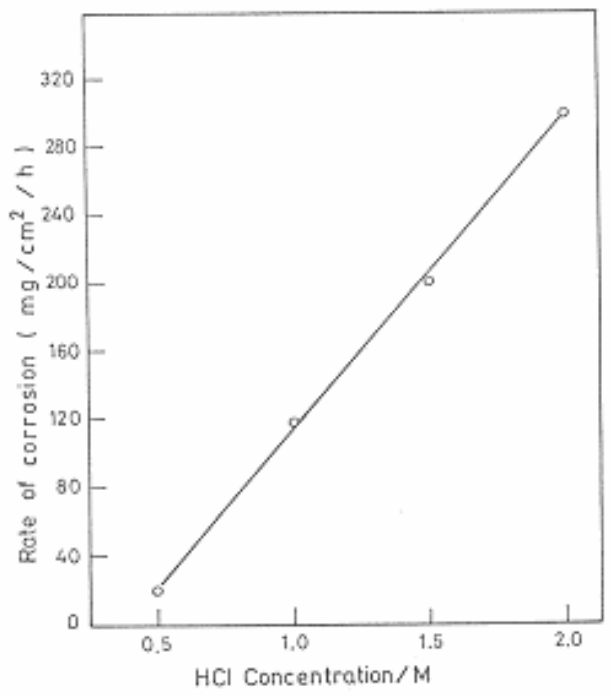

Figure 1. Corrosion rate of the alloy versus the concentration of $\mathrm{HCl}$ at $20{ }^{\circ} \mathrm{C}$ (weight loss measurements).

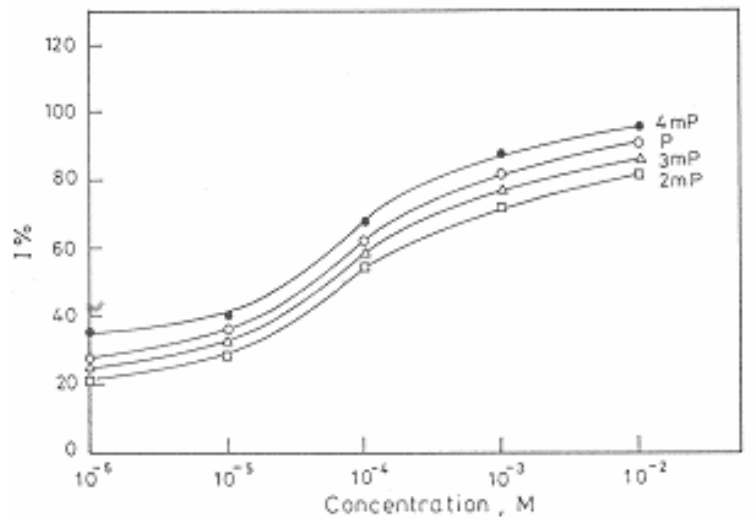

Figure 2. Effect of inhibitor concentration on the inhibition efficiency, I \%, at $20{ }^{\circ} \mathrm{C}$ (weight loss measurements).

\section{Results and discussion}

The corrosion behaviour of the investigated $\mathrm{Zn}-\mathrm{Al}-\mathrm{Cu}$ alloy was studied in hydrochloric acid solution with different concentrations $(0.5,1.0,1.5$ and $2.0 \mathrm{M})$ at $20^{\circ} \mathrm{C}$ by weight loss measurements. The results of this study are shown in Fig. 1 as corrosion rate, $R_{w},\left(\mathrm{mg} / \mathrm{cm}^{2} / \mathrm{h}\right)$ versus the molarity of the acid, and listed in Table 1. These results show that the corrosion rate of the investigated alloy greatly increases with the increase of acid concentration. To evaluate the inhibition efficiency of pyridine and its derivatives for the corrosion of the alloy, $0.5 \mathrm{M} \mathrm{HCl}$ solution was chosen as a corrosive medium. 
Table 1. Data of corrosion rate for the alloy in different concentrations of $\mathrm{HCl}$ at $20{ }^{\circ} \mathrm{C}$.

\begin{tabular}{cc}
\hline Conc./ M & $\mathrm{R}_{\mathrm{W}} /\left(\mathrm{mg} / \mathrm{cm}^{2} / \mathrm{h}\right)$ \\
\hline 0.5 & 20 \\
1.0 & 120 \\
1.5 & 200 \\
2.5 & 300 \\
\hline
\end{tabular}

Table 2. Data of weight loss measurements for the alloy in $0.5 \mathrm{M} \mathrm{HCl}$ in the presence of different concentrations of $\mathrm{p}$ at $20^{\circ} \mathrm{C}$.

\begin{tabular}{cccc}
\hline Conc. $/ \mathrm{M}$ & $\mathrm{R}_{\mathrm{W}} /\left(\mathrm{mg} / \mathrm{cm}^{2} / \mathrm{h}\right)$ & $\theta$ & $\mathrm{I} \%$ \\
\hline $1 \times 10^{-6}$ & 14.4 & 0.28 & 28 \\
$1 \times 10^{-5}$ & 12.8 & 0.36 & 36 \\
$1 \times 10^{-4}$ & 7.6 & 0.62 & 62 \\
$1 \times 10^{-3}$ & 3.6 & 0.82 & 82 \\
$1 \times 10^{-2}$ & 2.0 & 0.90 & 90 \\
\hline
\end{tabular}

Table 3. Data of weight loss measurements for the alloy in $0.5 \mathrm{M} \mathrm{HCl}$ in the presence of different concentrations of $2 \mathrm{mp}$ at $20^{\circ} \mathrm{C}$.

\begin{tabular}{cccc}
\hline Conc. $/ \mathrm{M}$ & $\mathrm{R}_{\mathrm{W}} /\left(\mathrm{mg} / \mathrm{cm}^{2} / \mathrm{h}\right)$ & $\theta$ & $\mathrm{I} \%$ \\
\hline $1 \times 10^{-6}$ & 15.6 & 0.22 & 22 \\
$1 \times 10^{-5}$ & 14.2 & 0.29 & 29 \\
$1 \times 10^{-4}$ & 9.0 & 0.55 & 55 \\
$1 \times 10^{-3}$ & 5.6 & 0.72 & 72 \\
$1 \times 10^{-2}$ & 3.6 & 0.82 & 82 \\
\hline
\end{tabular}

Tables 2-5 show the results of weight loss measurements carried out on the investigated alloy in $0.5 \mathrm{M} \mathrm{HCl}$ solution as corrosive medium in the presence of different concentrations of the inhibitors ( $\mathrm{p}, 2 \mathrm{mp}, 3 \mathrm{mp}, 4 \mathrm{mp}$ ), respectively. The values of surface coverage $(\theta)$ and inhibition efficiency ( $\mathrm{I} \%$ ) of the investigated compounds were calculated from the corrosion rates, $\mathrm{R}_{\mathrm{w}}$, listed in Tables 2-5 by using the following equations:

$$
\theta=1-\frac{\left(R_{w}\right)_{\text {inh }}}{\left(R_{w}\right) \text { free }}
$$




$$
I \%=\left[1-\frac{\left(R_{w}\right)_{\text {inh }}}{\left(R_{w}\right) \text { free }}\right] \times 100
$$

where $\left(R_{w}\right)_{\text {free }}$ and $\left(R_{w}\right)_{\text {inh }}$ are the corrosion rates $\left(\mathrm{mg} / \mathrm{cm}^{2} / \mathrm{h}\right)$ in the absence and in presence of the inhibitor. The calculated values are listed in Tables 2-5.

Table 4. Data of weight loss measurements for the alloy in $0.5 \mathrm{M} \mathrm{HCl}$ in the presence of different concentrations of $3 \mathrm{mp}$ at $20^{\circ} \mathrm{C}$.

\begin{tabular}{cccc}
\hline Conc. $/ \mathrm{M}$ & $\mathrm{R}_{\mathrm{W}} /\left(\mathrm{mg} / \mathrm{cm}^{2} / \mathrm{h}\right)$ & $\theta$ & $\mathrm{I} \%$ \\
\hline $1 \times 10^{-6}$ & 15.0 & 0.25 & 25 \\
$1 \times 10^{-5}$ & 13.6 & 0.32 & 32 \\
$1 \times 10^{-4}$ & 8.4 & 0.58 & 58 \\
$1 \times 10^{-3}$ & 4.8 & 0.76 & 76 \\
$1 \times 10^{-2}$ & 3.0 & 0.85 & 85 \\
\hline
\end{tabular}

Table 5. Data of weight loss measurements for the alloy in $0.5 \mathrm{M} \mathrm{HCl}$ in the presence of different concentrations of $4 \mathrm{mp}$ at $20^{\circ} \mathrm{C}$.

\begin{tabular}{cccc}
\hline Conc. $/ \mathrm{M}$ & $\mathrm{R}_{\mathrm{W}} /\left(\mathrm{mg} / \mathrm{cm}^{2} / \mathrm{h}\right)$ & $\theta$ & $\mathrm{I} \%$ \\
\hline $1 \times 10^{-6}$ & 13.0 & 0.35 & 35 \\
$1 \times 10^{-5}$ & 12.0 & 0.40 & 40 \\
$1 \times 10^{-4}$ & 6.4 & 0.68 & 68 \\
$1 \times 10^{-3}$ & 2.4 & 0.88 & 88 \\
$1 \times 10^{-2}$ & 1.0 & 0.95 & 95 \\
\hline
\end{tabular}

Fig. 2 represents the effect of inhibitors concentration on the inhibition efficiency $(\mathrm{I} \%)$ at $20^{\circ} \mathrm{C}$. These plots have S-shape and the inhibition efficiency of the investigated compounds increasing according to the order: $2 \mathrm{mp}<3 \mathrm{mp}<\mathrm{p}<4$ $\mathrm{mp}$. It is indicated from the results of Tables 2-5 that the value of surface coverage $(\theta)$ and inhibition efficiency $(\mathrm{I} \%)$ increases with the increase of the inhibitor concentration. Also, at a given concentration the surface coverage, $\theta$, and inhibition efficiency, I\%, increase according to the order $2 \mathrm{mp}<3 \mathrm{mp}<\mathrm{p}<$ $4 \mathrm{mp}$.

Fig. 3 represents the plots of linear polarization measurements (E-i) for the alloy in $0.5 \mathrm{M} \mathrm{HCl}$ solutions in the absence and in presence of different concentrations of pyridine (p). Similar plots were obtained for the other three compounds $2 \mathrm{mp}$, $3 \mathrm{mp}$ and $4 \mathrm{mp}$ and not shown. The different values of polarization resistance, $\mathrm{R}_{\mathrm{p}}$, were deduced from the slopes $\left(\Delta \mathrm{E} / \Delta \mathrm{i}=\mathrm{R}_{\mathrm{p}}\right)$ of the straight lines of Fig. 3 and 
similar ones are listed in Tables 6-9 for the investigated compounds (p, $2 \mathrm{mp}, 3$ $\mathrm{mp}, 4 \mathrm{mp}$ ), respectively. The values of surface coverage, $\theta$, and inhibition efficiency, $\mathrm{I} \%$, were calculated from $\mathrm{R}_{\mathrm{p}}$ values using the following equations:

$$
\begin{gathered}
\theta=1-\frac{\left(R_{p}\right)_{\text {free }}}{(R p)_{\text {inh }}} \\
I \%=\left[1-\frac{\left(R_{p}\right)_{\text {free }}}{(R p)_{\text {inh }}}\right] \times 100
\end{gathered}
$$

where $\left(R_{p}\right)_{\text {free }}$ and $\left(R_{p}\right)_{\text {inh }}$ are the polarization resistances in absence and in presence of the inhibitor, respectively. The calculated values of $\theta$ and $\mathrm{I} \%$ are listed in Tables 6-9 for the investigated compounds (p, $2 \mathrm{mp}, 3 \mathrm{mp}, 4 \mathrm{mp}$ ), respectively.

Table 6. Data of linear polarization measurements for the alloy in $0.5 \mathrm{M} \mathrm{HCl}$ in the presence of different concentrations of $\mathrm{p}$ at $20^{\circ} \mathrm{C}$.

\begin{tabular}{cccc}
\hline Conc. $/ \mathrm{M}$ & $\mathrm{R}_{\mathrm{P}} /\left(\Omega / \mathrm{cm}^{2} / \mathrm{h}\right)$ & $\theta$ & $\mathrm{I} \%$ \\
\hline 0.00 & 270 & - & - \\
$1 \times 10^{-6}$ & 369.86 & 0.27 & 27 \\
$1 \times 10^{-5}$ & 415.38 & 0.35 & 35 \\
$1 \times 10^{-4}$ & 710.53 & 0.62 & 62 \\
$1 \times 10^{-3}$ & 1421.05 & 0.81 & 81 \\
$1 \times 10^{-2}$ & 3000 & 0.91 & 91 \\
\hline
\end{tabular}

Table 7. Data of linear polarization measurements for the alloy in $0.5 \mathrm{M} \mathrm{HCl}$ in the presence of different concentrations of $2 \mathrm{mp}$ at $20^{\circ} \mathrm{C}$.

\begin{tabular}{cccc}
\hline Conc. / M & $\mathrm{R}_{\mathrm{P}} /\left(\Omega / \mathrm{cm}^{2} / \mathrm{h}\right)$ & $\theta$ & $\mathrm{I} \%$ \\
\hline 0.00 & 270 & - & - \\
$1 \times 10^{-6}$ & 341.77 & 0.21 & 21 \\
$1 \times 10^{-5}$ & 380.28 & 0.29 & 29 \\
$1 \times 10^{-4}$ & 586.96 & 0.54 & 54 \\
$1 \times 10^{-3}$ & 931.03 & 0.71 & 71 \\
$1 \times 10^{-2}$ & 1350 & 0.80 & 80
\end{tabular}




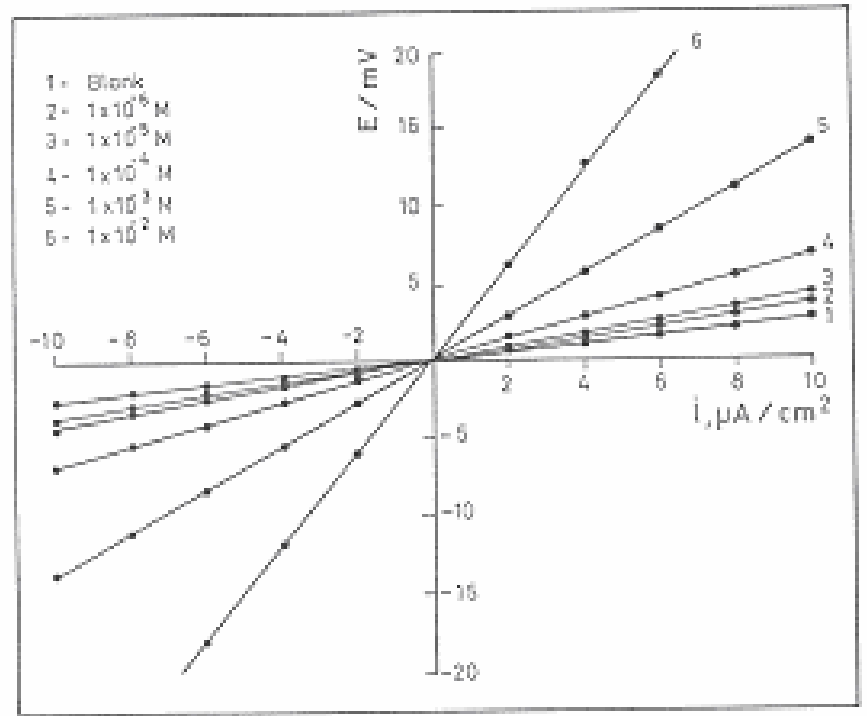

Figure 3. E-i plots in pure $0.5 \mathrm{M} \mathrm{HCl}$ and in the presence of different concentrations of $\mathrm{p}$ at $20^{\circ} \mathrm{C}$.

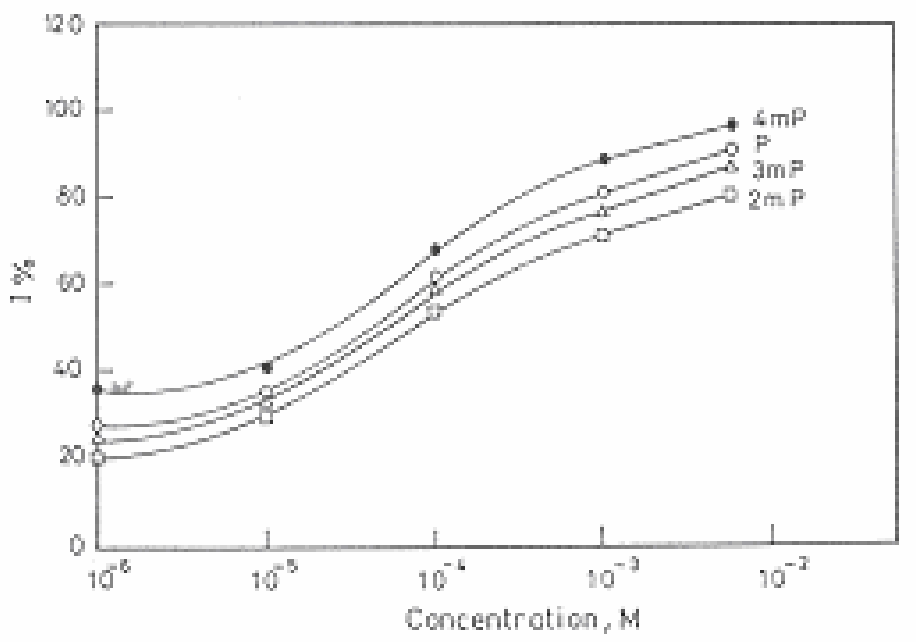

Figure 4. Effect of inhibitor concentration on the inhibition efficiency I \%, at $20^{\circ} \mathrm{C}$.

Fig. 4 represents the effect of the inhibitor concentration on the inhibition efficiency of the investigated compounds. The obtained plots have S-shape. From these plots and results listed in Tables 6-9 it is indicated that the values of $\theta$ and I\% for the investigated compounds increase according to the order: $2 \mathrm{mp}<3 \mathrm{mp}$ $<\mathrm{p}<4 \mathrm{mp}$. This order is in agreement with that obtained from the weight loss measurements. 
Table 8. Data of linear polarization measurements for the alloy in $0.5 \mathrm{M} \mathrm{HCl}$ in the presence of different concentrations of $3 \mathrm{mp}$ at $20^{\circ} \mathrm{C}$.

\begin{tabular}{cccc}
\hline Conc. / M & $\mathrm{R}_{\mathrm{P}} /\left(\Omega / \mathrm{cm}^{2} / \mathrm{h}\right)$ & $\theta$ & $\mathrm{I} \%$ \\
\hline 0.00 & 270 & - & - \\
$1 \times 10^{-6}$ & 360 & 0.25 & 25 \\
$1 \times 10^{-5}$ & 402.99 & 0.33 & 33 \\
$1 \times 10^{-4}$ & 658.54 & 0.59 & 59 \\
$1 \times 10^{-3}$ & 1125 & 0.76 & 76 \\
$1 \times 10^{-2}$ & 1928.57 & 0.86 & 86 \\
\hline
\end{tabular}

Table 9. Data of linear polarization measurements for the alloy in $0.5 \mathrm{M} \mathrm{HCl}$ in the presence of different concentrations of $4 \mathrm{mp}$ at $20^{\circ} \mathrm{C}$.

\begin{tabular}{cccc}
\hline Conc. / M & $\mathrm{R}_{\mathrm{P}} /\left(\Omega / \mathrm{cm}^{2} / \mathrm{h}\right)$ & $\theta$ & $\mathrm{I} \%$ \\
\hline 0.00 & 270 & - & - \\
$1 \times 10^{-6}$ & 421.88 & 0.36 & 36 \\
$1 \times 10^{-5}$ & 457.63 & 0.41 & 41 \\
$1 \times 10^{-4}$ & 843.75 & 0.68 & 68 \\
$1 \times 10^{-3}$ & 2454.55 & 0.89 & 89 \\
$1 \times 10^{-2}$ & 6750 & 0.96 & 96 \\
\hline
\end{tabular}

Fig. 5 represents the galvanostatic cathodic and anodic polarization curves for the alloy in $0.5 \mathrm{M} \mathrm{HCl}$ in the absence and in the presence of different concentrations of pyridine (p). Similar plots were obtained for the alloy in the presence of different concentrations of the other three organic additives ( $2 \mathrm{mp}, 3 \mathrm{mp}, 4 \mathrm{mp}$ ) and not shown. The different values of surface coverage, $\theta$, and inhibition efficiency, I\%, were calculated from the corresponding values of corrosion current densities by using the following equations:

$$
\begin{gathered}
\theta=1-\frac{\left(i_{\text {corr }}\right)_{\text {inh }}}{\left(i_{\text {corr }}\right) \text { free }} \\
I \%=\left[1-\frac{\left(i_{\text {corr }}\right)_{\text {inh }}}{\left(i_{\text {corr }}\right) \text { free }}\right] \times 100
\end{gathered}
$$

where $\left(i_{\text {corr }}\right)_{\text {free }}$ and $\left(i_{\text {corr }}\right)_{\text {inh }}$ are the values of current density in the absence and in the presence of the inhibitor, respectively. The values of corrosion current density are deduced from the polarization curves of Fig. 5 and similar ones by 
extrapolating the Tafel's lines. The calculated values of $\mathrm{i}_{\text {corr }}, \theta$, and $\mathrm{I} \%$ are listed in Tables 10-13.

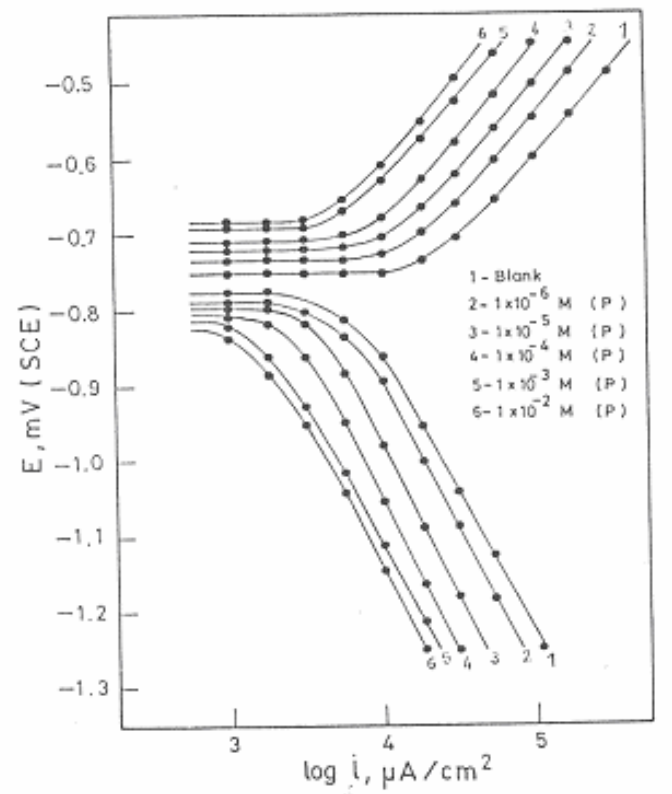

Figure 5. Galvanostatic polarization curves for the alloy in pure $0.5 \mathrm{M} \mathrm{HCl}$ and in the presence of different concentrations of $\mathrm{p}$ at $20^{\circ} \mathrm{C}$.

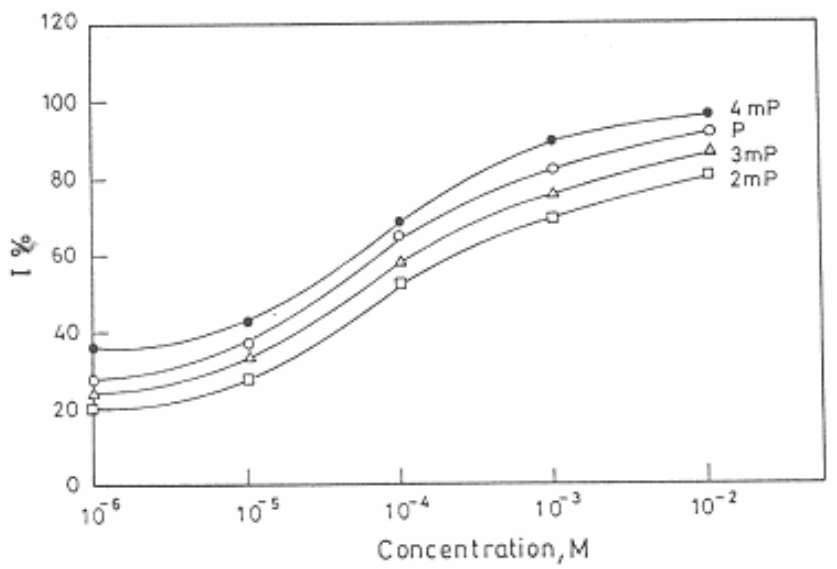

Figure 6. Effect of inhibitor concentration on the inhibition efficiency I \%, at $20^{\circ} \mathrm{C}$.

Table 10. Data of galvanostatic polarization measurements for the alloy in $0.5 \mathrm{M} \mathrm{HCl}$ in the presence of different concentrations of $\mathrm{p}$ at $20^{\circ} \mathrm{C}$.

\begin{tabular}{cccc}
\hline Conc. $/ \mathrm{M}$ & $\mathrm{I}_{\text {corr }} /\left(\mu \mathrm{A} / \mathrm{cm}^{2}\right)$ & $\theta$ & $\mathrm{I} \%$ \\
\hline 0.00 & 1500 & $\overline{0}$ & $\overline{28}$ \\
$1 \times 10^{-6}$ & 1080 & 0.28 & 36 \\
$1 \times 10^{-5}$ & 960 & 0.36 & 64 \\
$1 \times 10^{-4}$ & 540 & 0.64 & 82 \\
$1 \times 10^{-3}$ & 270 & 0.82 & 92 \\
$1 \times 10^{-2}$ & 120 & 0.92 & \\
& & &
\end{tabular}


Table 11. Data of galvanostatic polarization measurements for the alloy in $0.5 \mathrm{M} \mathrm{HCl}$ in the presence of different concentrations of $2 \mathrm{mp}$ at $20^{\circ} \mathrm{C}$.

\begin{tabular}{cccc}
\hline Conc. $/ \mathrm{M}$ & $\mathrm{I}_{\text {corr }} /\left(\mu \mathrm{A} / \mathrm{cm}^{2}\right)$ & $\theta$ & $\mathrm{I} \%$ \\
\hline 0.00 & 1500 & - & - \\
$1 \times 10^{-6}$ & 1200 & 0.20 & 20 \\
$1 \times 10^{-5}$ & 1080 & 0.28 & 28 \\
$1 \times 10^{-4}$ & 705 & 0.53 & 53 \\
$1 \times 10^{-3}$ & 450 & 0.70 & 70 \\
$1 \times 10^{-2}$ & 300 & 0.80 & 80 \\
\hline
\end{tabular}

Table 12. Data of galvanostatic polarization measurements for the alloy in $0.5 \mathrm{M} \mathrm{HCl}$ in the presence of different concentrations of $3 \mathrm{mp}$ at $20^{\circ} \mathrm{C}$.

\begin{tabular}{cccc}
\hline Conc. $/ \mathrm{M}$ & $\mathrm{I}_{\text {corr }} /\left(\mu \mathrm{A} / \mathrm{cm}^{2}\right)$ & $\theta$ & $\mathrm{I} \%$ \\
\hline 0.00 & 1500 & - & - \\
$1 \times 10^{-6}$ & 1140 & 0.24 & 24 \\
$1 \times 10^{-5}$ & 990 & 0.34 & 34 \\
$1 \times 10^{-4}$ & 630 & 0.58 & 58 \\
$1 \times 10^{-3}$ & 375 & 0.75 & 75 \\
$1 \times 10^{-2}$ & 225 & 0.85 & 85 \\
\hline
\end{tabular}

Table 13. Data of galvanostatic polarization measurements for the alloy in $0.5 \mathrm{M} \mathrm{HCl}$ in the presence of different concentrations of $4 \mathrm{mp}$ at $20^{\circ} \mathrm{C}$.

\begin{tabular}{cccc}
\hline Conc. $/ \mathrm{M}$ & $\mathrm{I}_{\text {corr }} /\left(\mu \mathrm{A} / \mathrm{cm}^{2}\right)$ & $\theta$ & $\mathrm{I} \%$ \\
\hline 0.00 & 1500 & - & - \\
$1 \times 10^{-6}$ & 945 & 0.37 & 37 \\
$1 \times 10^{-5}$ & 870 & 0.42 & 42 \\
$1 \times 10^{-4}$ & 480 & 0.68 & 68 \\
$1 \times 10^{-3}$ & 150 & 0.90 & 90 \\
$1 \times 10^{-2}$ & 60 & 0.96 & 96 \\
\hline
\end{tabular}




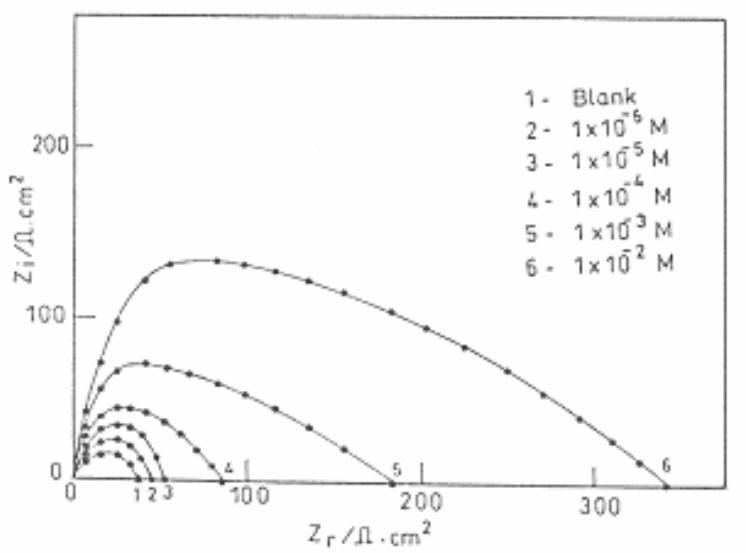

Figure 7. Nyquist plot for the alloy in $0.5 \mathrm{M} \mathrm{HCl}$ in the absence and in the presence of different concentrations of $\mathrm{p}$ at $20^{\circ} \mathrm{C}$.

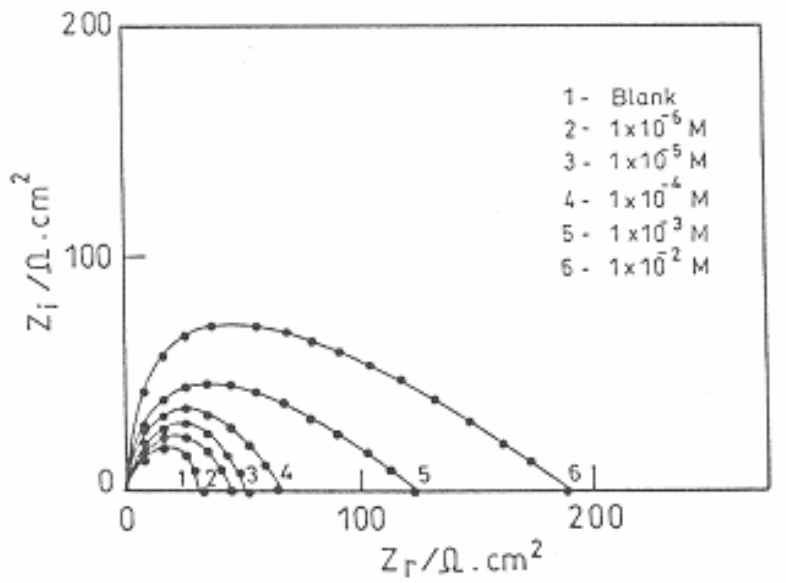

Figure 8. Nyquist plot for the alloy in $0.5 \mathrm{M} \mathrm{HCl}$ in the absence and in the presence of different concentrations of $2 \mathrm{mp}$ at $20^{\circ} \mathrm{C}$.

Fig. 6 represents the plots of inhibition efficiency, I\%, against the concentration of the inhibitors. The obtained plots have S-shape as above mentioned. From the results of Tables 10-13 and Fig. 6 , it can be seen that the values of $\theta$ and $\mathrm{I} \%$ of the investigated organic compounds increase according to the order: $2 \mathrm{mp}<3 \mathrm{mp}$ $<\mathrm{p}<4 \mathrm{mp}$. This order is in agreement with those obtained by weight loss and linear polarization measurements.

Figs. 7-10 represent the impedance diagrams (Nyquist plots) for the alloy in 0.5 $\mathrm{M} \mathrm{HCl}$ and in the presence of increasing concentrations of the investigated organic compounds ( $\mathrm{p}, 2 \mathrm{mp}, 3 \mathrm{mp}, 4 \mathrm{mp})$, respectively, at $20{ }^{\circ} \mathrm{C}$. The charge transfer resistance values $\left(\mathrm{R}_{\mathrm{t}}\right)$ are calculated from the difference in the impedance at lower and higher frequencies [13].

The double layer capacitance, $\mathrm{C}_{\mathrm{dl}}$, was determined from the frequency, $\mathrm{f}$, at which $t_{i}$ was maximum, using the relationship:

$$
f\left(-t_{i, \max }\right)=\left(2 \pi C_{d l} R_{t}\right)^{-1}
$$


The inhibition efficiency, $\mathrm{I} \%$, of the working electrode is calculated from the charge transfer, $\mathrm{R}_{\mathrm{t}}$, using the equation:

$$
I \%=\frac{R_{\text {tcorr }}^{-1}-R_{\text {tcorr }(\text { inh })}^{-1}}{R_{\text {tcorr }}^{-1}} \times 100
$$

where $R_{t \text { corr }}$ and $R_{t \text { corr(inh) }}$ are the charge transfer resistance values in the absence and in the presence of the inhibitor, respectively.

The values of $\mathrm{R}_{\mathrm{t}}, \mathrm{C}_{\mathrm{dl}}$ and $\mathrm{I} \%$ derived from impedance measurements are shown in Tables 14-17 for the investigated organic compounds ( $\mathrm{p}, 2 \mathrm{mp}, 3 \mathrm{mp}, 4 \mathrm{mp}$ ), respectively.

Table 14. Data of impedance measurements for the alloy in $0.5 \mathrm{M} \mathrm{HCl}$ in the absence and in the presence of different concentrations of compound $\mathrm{p}$ at $20^{\circ} \mathrm{C}$.

\begin{tabular}{cccc}
\hline Conc. $/ \mathrm{M}$ & $\mathrm{R}_{\mathrm{t}} /\left(\Omega . \mathrm{cm}^{2}\right)$ & $\mathrm{C}_{\mathrm{dl}} /\left(\mathrm{MF} . \mathrm{cm}^{-2}\right)$ & $\mathrm{I} \%$ \\
\hline 0.00 & 30 & 7372 & - \\
$1 \times 10^{-6}$ & 42.5 & 3085 & 29 \\
$1 \times 10^{-5}$ & 47.7 & 2303 & 37 \\
$1 \times 10^{-4}$ & 79 & 1049.8 & 62 \\
$1 \times 10^{-3}$ & 176.5 & 299.9 & 83 \\
$1 \times 10^{-2}$ & 333.34 & 88.6 & 91
\end{tabular}

Table 15. Data of impedance measurements for the alloy in $0.5 \mathrm{M} \mathrm{HCl}$ in the absence and in the presence of different concentrations of compound $2 \mathrm{mp}$ at $20^{\circ} \mathrm{C}$.

\begin{tabular}{cccc}
\hline Conc. $/ \mathrm{M}$ & $\mathrm{R}_{\mathrm{t}} /\left(\Omega . \mathrm{cm}^{2}\right)$ & $\mathrm{C}_{\mathrm{dl}} /\left(\mathrm{MF} . \mathrm{cm}^{-2}\right)$ & $\mathrm{I} \%$ \\
\hline 0.00 & 30 & 7372 & - \\
$1 \times 10^{-6}$ & 39 & 4089.7 & 23 \\
$1 \times 10^{-5}$ & 42.9 & 3050 & 30 \\
$1 \times 10^{-4}$ & 68.2 & 1667.74 & 56 \\
$1 \times 10^{-3}$ & 111.2 & 716 & 73 \\
$1 \times 10^{-2}$ & 176.2 & 300.5 & 83 \\
\hline
\end{tabular}

The results on these Tables indicate that as the inhibitors concentration increases, the values of $R_{t}$ and $I \%$ increase, but the values of $C_{d l}$ decrease, indicating the occurrence of adsorption of the inhibitors on the electrode surface. Their inhibition efficiency increases according to the order: $2 \mathrm{mp}<3 \mathrm{mp}<\mathrm{p}<4 \mathrm{mp}$. This order is the same as that obtained by the previously mentioned techniques. 


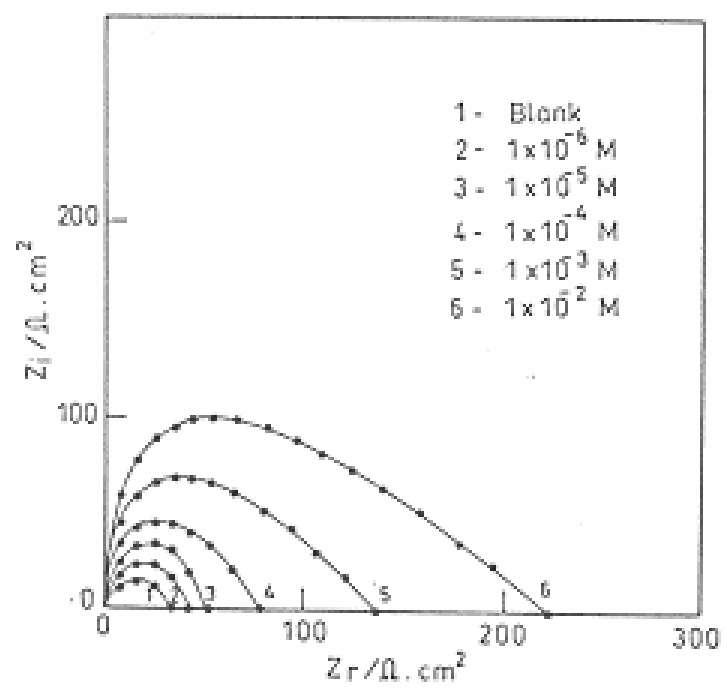

Figure 9. Nyquist plot for the alloy in $0.5 \mathrm{M} \mathrm{HCl}$ in the absence and in the presence of different concentrations of $3 \mathrm{mp}$ at $20^{\circ} \mathrm{C}$.

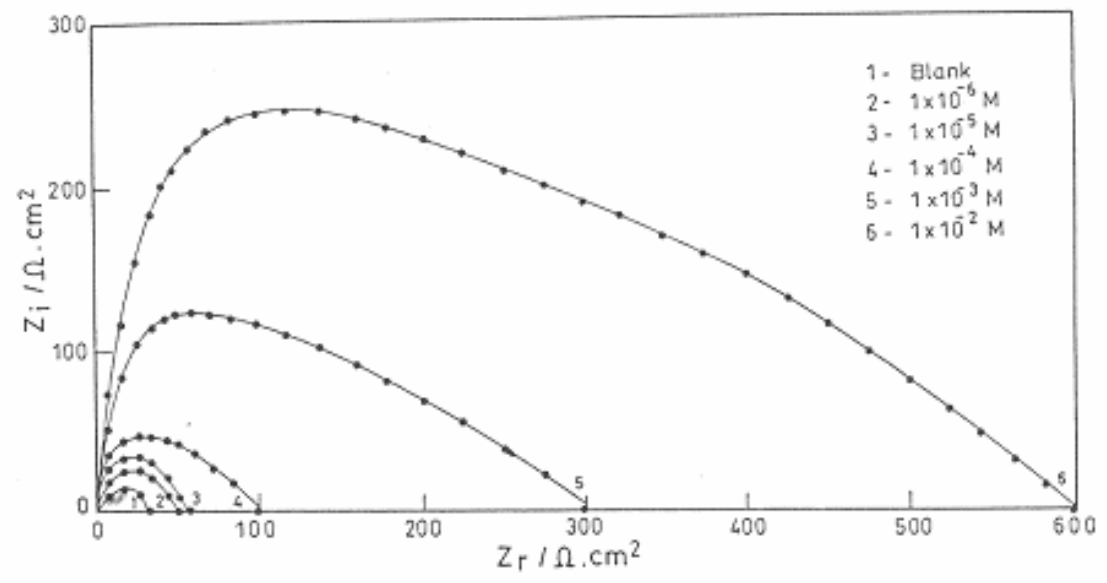

Figure 10. Nyquist plot for the alloy in $0.5 \mathrm{M} \mathrm{HCl}$ in the absence and in the presence of different concentrations of $4 \mathrm{mp}$ at $20^{\circ} \mathrm{C}$.

The corrosion penetration, $\mathrm{CP}$, of the alloy can be calculated from the weight loss measurements using the equation [14]

$$
\mathrm{CP}=\mathrm{w} / \mathrm{Ad}
$$

where $\mathrm{w}$ is the weight loss in grams, A is the surface area of the specimen $\left(\mathrm{cm}^{2}\right)$ and $\mathrm{d}$ is the density of the alloy $\left(\cong 7 \mathrm{~g} / \mathrm{cm}^{2}\right)$. The values of corrosion penetration, $\mathrm{CP}$, are calculated using equation (9) for the alloy specimens in $0.5 \mathrm{M} \mathrm{HCl}$ in the absence and in the presence of $10^{-3} \mathrm{M}$ of inhibitors at different immersion time $\left(1,2,3,4,5\right.$ hours) at $20{ }^{\circ} \mathrm{C}$ and listed in Table 18. 
Table 16. Data of impedance measurements for the alloy in $0.5 \mathrm{M} \mathrm{HCl}$ in the absence and in the presence of different concentrations of compound $3 \mathrm{mp}$ at $20^{\circ} \mathrm{C}$.

\begin{tabular}{cccc}
\hline Conc. $/ \mathrm{M}$ & $\mathrm{R}_{\mathrm{t}} /\left(\Omega . \mathrm{cm}^{2}\right)$ & $\mathrm{C}_{\mathrm{dl}} /\left(\mathrm{MF} . \mathrm{cm}^{-2}\right)$ & $\mathrm{I} \%$ \\
\hline 0.00 & 30 & 7372 & - \\
$1 \times 10^{-6}$ & 40.5 & 3931.75 & 26 \\
$1 \times 10^{-5}$ & 44.8 & 2417.8 & 33 \\
$1 \times 10^{-4}$ & 71.5 & 1105.8 & 58 \\
$1 \times 10^{-3}$ & 130.5 & 435.8 & 77 \\
$1 \times 10^{-2}$ & 214.5 & 185.16 & 86 \\
\hline
\end{tabular}

Table 17. Data of impedance measurements for the alloy in $0.5 \mathrm{M} \mathrm{HCl}$ in the absence and in the presence of different concentrations of compound $4 \mathrm{mp}$ at $20^{\circ} \mathrm{C}$.

\begin{tabular}{cccc}
\hline Conc. $/ \mathrm{M}$ & $\mathrm{R}_{\mathrm{t}} /\left(\Omega . \mathrm{cm}^{2}\right)$ & $\mathrm{C}_{\mathrm{dl}} /\left(\mathrm{MF} . \mathrm{cm}^{-2}\right)$ & $\mathrm{I} \%$ \\
\hline 0.00 & 30 & 7372 & - \\
$1 \times 10^{-6}$ & 46.9 & 3025 & 36 \\
$1 \times 10^{-5}$ & 50.9 & 2109.7 & 41 \\
$1 \times 10^{-4}$ & 93.8 & 847 & 68 \\
$1 \times 10^{-3}$ & 300 & 106.16 & 90 \\
$1 \times 10^{-2}$ & 600 & 26.54 & 95 \\
\hline
\end{tabular}

Figs. 11 and 12 represent the plots of the corrosion penetration, $\mathrm{CP}$, versus the square root of immersion time $\left(\mathrm{t}^{1 / 2}\right)$ for the alloy in $0.2 \mathrm{M} \mathrm{HCl}$ in the absence and in the presence of $10^{-3} \mathrm{M}$ of inhibitors, respectively, at $20{ }^{\circ} \mathrm{C}$. The lines of these figures indicate that the corrosion reaction of the alloy in these media follows the parabolic rate law as in the following equation:

$$
\mathrm{X}=k \mathrm{t}^{1 / 2}
$$

where $\mathrm{X}$ is the measure of corrosion extent (i.e., CP), $\mathrm{t}$ is the immersion time, and $\mathrm{k}$ is the parabolic rate constant $\left(\mathrm{cm} \cdot \mathrm{h}^{-1 / 2}\right)$. The values of $\mathrm{k}$ are deduced from the slopes of straight lines of Fig. 11 and 12 for the alloy in $0.5 \mathrm{M} \mathrm{HCl}$ in the absence and in the presence of $10^{-3} \mathrm{M}$ of the inhibitors and listed in Table 18 . These results indicate that the presence of the investigated organic compounds in $0.5 \mathrm{M} \mathrm{HCl}$ greatly decreases the values of $\mathrm{CP}$ and $\mathrm{k}$ according to the order: $2 \mathrm{mp}$ $>3 \mathrm{mp}>\mathrm{p}>4 \mathrm{mp}$. This means that these compounds have high inhibiting efficiency which increases according to the order: $2 \mathrm{mp}<3 \mathrm{mp}<\mathrm{p}<4 \mathrm{mp}$. This order is the same as that obtained by the previously mentioned determinations, indicating the suitability of these corrosion penetration calculations for the evaluation of the corrosion extent in these media. 


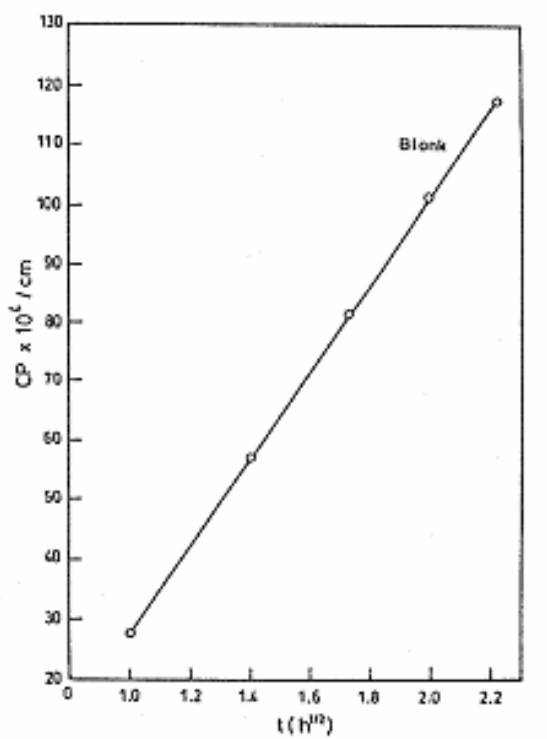

Figure 11. Plots of corrosion penetration versus $\mathrm{t}^{1 / 2}$ for the alloy in $0.5 \mathrm{M} \mathrm{HCl}$.

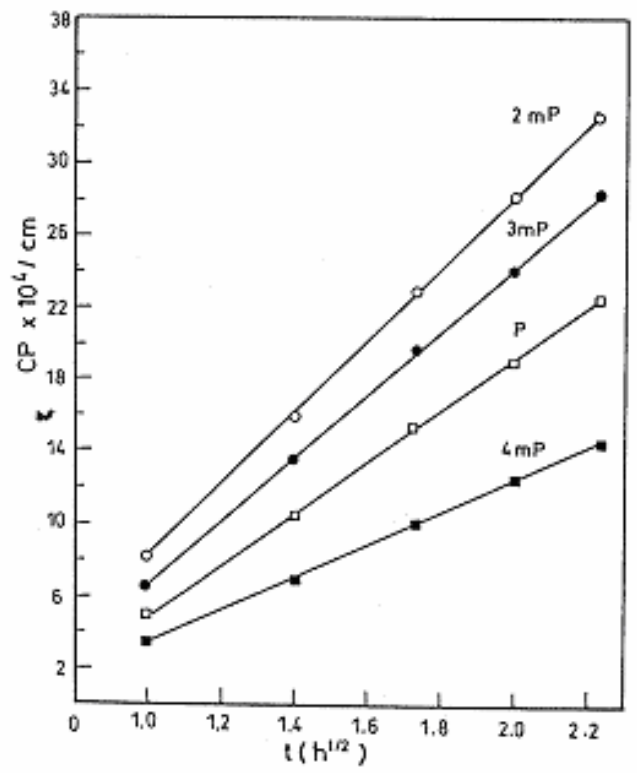

Figure 12. Plots of corrosion penetration versus $t^{1 / 2}$ for the alloy in $0.5 \mathrm{M} \mathrm{HCl}$ containing $10^{-3} \mathrm{M}$ of the inhibitors.

The results of this investigation indicate that there is a good agreement between the results obtained by different techniques of measurements used in this investigation for the determination of corrosion rates of the alloy in $0.5 \mathrm{M} \mathrm{HCl}$ in the absence and in the presence of different concentrations of the investigated inhibitors.

The results of Fig. 1 and Table 1 indicate that the corrosion rate, $R_{w}$, of the investigated alloy greatly increases with the increase of the acid concentration, where it increases by 15 times to each 4 times of the acid concentration increasing. Also the corrosion rate of this alloy in $\mathrm{HCl}$ solution is greatly higher 
than that of aluminium [15] and zinc metal [16-18]. It was found [5] that the rate of cathodic reaction in $\mathrm{Zn}-\mathrm{A} 1$ plating was faster than in zinc plating, state of which confirms the results of the present investigation. It was reported $[1,2,4]$ that the mechanism of corrosion of the alloy was proceeding in two discrete steps. The first one is the general attack of the surface involving predominantly the corrosion of the zinc phase of the alloy concentrations on the interdendritic zones, hence creating pores into the matrix after the zinc has been consumed by the corrosion, the aluminium dendrites being attacked within the matrix via chloride transport into these pores.

Table 18. Data of corrosion penetration for the alloy in $0.5 \mathrm{M} \mathrm{HCl}$ solution and in the presence of $10^{-3} \mathrm{M}$ of the inhibitor at $20^{\circ} \mathrm{C}$.

\begin{tabular}{|c|c|c|c|c|c|}
\hline \multirow{2}{*}{$\begin{array}{c}\text { Time } \\
(\mathrm{h})\end{array}$} & \multicolumn{5}{|c|}{$(\mathrm{CP} / \mathrm{cm})$} \\
\cline { 2 - 6 } & blank & $\mathrm{p}$ & $2 \mathrm{mp}$ & $3 \mathrm{mp}$ & $4 \mathrm{mp}$ \\
\hline 1 & $2.857 \times 10^{-3}$ & $5.143 \times 10^{-4}$ & $8 \times 10^{-4}$ & $6.857 \times 10^{-4}$ & $3.424 \times 10^{-4}$ \\
2 & $5.714 \times 10^{-3}$ & $1.028 \times 10^{-3}$ & $1.6 \times 10^{-3}$ & $1.3714 \times 10^{-3}$ & $6.857 \times 10^{-4}$ \\
3 & $8.25 \times 10^{-3}$ & $1.543 \times 10^{-3}$ & $2.4 \times 10^{-3}$ & $2.0 \times 10^{-3}$ & $1.0 \times 10^{-3}$ \\
4 & $10.25 \times 10^{-3}$ & $1.9 \times 10^{-3}$ & $2.8 \times 10^{-3}$ & $2.4 \times 10^{-3}$ & $1.25 \times 10^{-3}$ \\
5 & $11.75 \times 10^{-3}$ & $2.25 \times 10^{-3}$ & $3.3 \times 10^{-3}$ & $2.85 \times 10^{-3}$ & $1.45 \times 10^{-3}$ \\
$\mathrm{k} /\left(\mathrm{cm} \cdot \mathrm{h}^{-1 / 2}\right)$ & $7.393 \times 10^{-3}$ & $1.386 \times 10^{-3}$ & $2 \times 10^{-3}$ & $1.72 \times 10^{-3}$ & $9.08 \times 10^{-4}$ \\
\hline
\end{tabular}

The results of Fig. 2, 4 and 6 indicate that the inhibition efficiency, I\%, slightly increases with the increase of the inhibitor concentration and then greatly increases reaching a limiting value (the curves have S-shape). In these media there is a competition between the active ions such as $\mathrm{Cl}$ ions and the inhibitor molecules for the adsorption onto the metallic surface. The absorbability of each one greatly depends on their relative concentrations. This means that the inhibitive effect of organic molecules depends on the concentration of $\mathrm{Cl}^{-}$, which decreases with increasing the ability of the inhibitor to form a protective layer on the metal surface.

Other authors [19,20] found that, for each additive, it is necessary to reach a particular concentration value before the additive to exert its inhibiting effect on the corrosion process; above this concentration the inhibiting efficiency firstly increases rapidly with concentration, then it increases more slowly tending asymptotically to a limiting value.

The obtained results indicated that the investigated compounds ( $\mathrm{p}, 2 \mathrm{mp}, 3 \mathrm{mp}, 4$ $\mathrm{mp}$ ) had a significant effect. This phenomenon was conferred by the presence of an electron donor group such as $\mathrm{N}$ in the pyridine structure. The presence of a free electron pair in $\mathrm{N}$ played the major role in the adsorption of the organic compound on the metallic surface. 


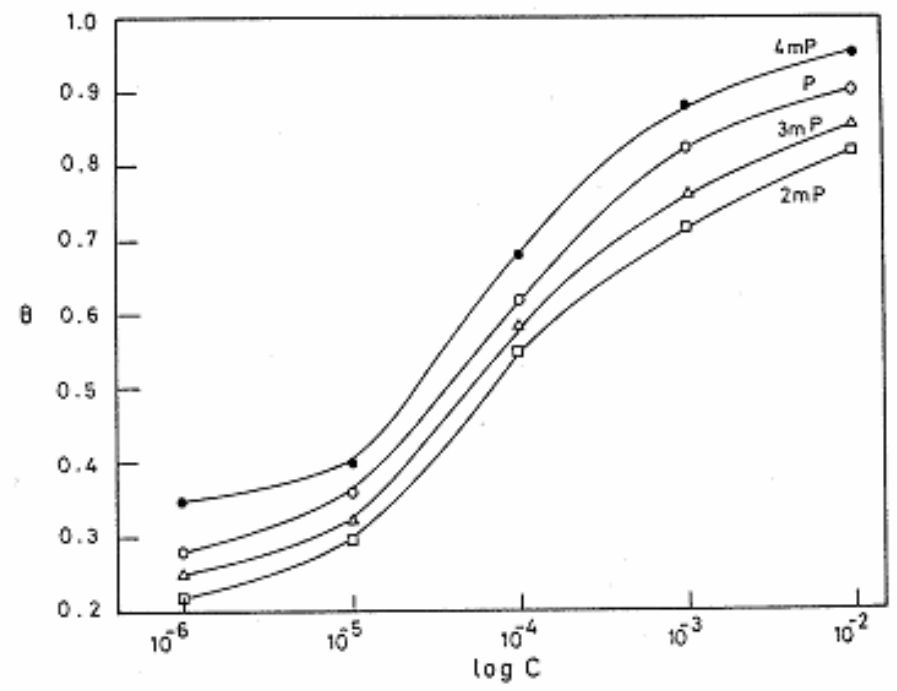

Figure 13. Frumkin's adsorption isotherms for the compounds onto the alloy surface at $20{ }^{\circ} \mathrm{C}$.

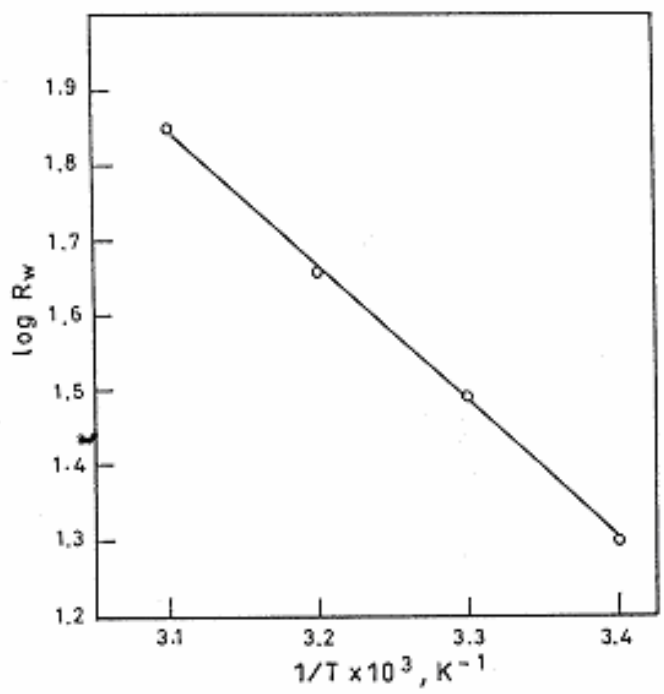

Figure 14. Arrhenius plots of $\log \mathrm{R}_{\mathrm{w}}$ against 1/Tin pure $0.5 \mathrm{M} \mathrm{HCl}$.

The relation between $\theta$ and $\log (\mathrm{C})$ had the character of an S-shaped adsorption isotherm, Fig. 13. This showed that the investigated inhibitors were adsorbed onto the alloy surface according to the Frumkin's isotherm [21]:

$$
\theta(1-\theta)^{-1} \exp (-f C)=K C
$$

where $\mathrm{K}$ is the equilibrium constant of adsorption, $\mathrm{f}$ is a function of adsorption energy, $\theta$ is the surface coverage, and $\mathrm{C}$ is the inhibitor concentration (M).

The results of galvanostatic polarization measurements, Fig. 5, and similar ones, indicated that the investigated compounds behave as mixed inhibitors, i.e., both the cathodic and anodic polarization curves are affected by the presence of inhibitors in the corrosive media. A similar behaviour for the mixed effect has 
been found in the literature [20,22,23]. In the present study it has been found that the magnitude of the displacement of the polarization curves appears to be dependent on the molecular structure of the inhibitor. Also, the cathodic and anodic Tafel's lines are more or less parallel, indicating that the hydrogen evolution and metal dissolution were activation controlled and the addition of the investigated compounds did not modify the mechanism of these processes $[22,24]$. Also, the inhibiting action of such compounds occurs by blocking of the electrode surface, thus decreasing the surface area available for the electrochemical reactions.

To determine the activation energies of the corrosion process, the weight loss measurements were taken at the temperatures $20,30,40$ and $50{ }^{\circ} \mathrm{C}$ in pure $0.5 \mathrm{M}$ $\mathrm{HCl}$ and in the presence of $10^{-3} \mathrm{M}$ of each of the investigated compounds. The obtained results are listed in Tables 19-23 for the pure acid and in the presence of $10^{-3} \mathrm{M}$ of the compounds ( $, 2 \mathrm{mp}, 3 \mathrm{mp}, 4 \mathrm{mp}$ ), respectively. The results of these tables indicated that the rate of corrosion $\left(\mathrm{R}_{\mathrm{w}}\right)$ increases with the increase of the temperature. On the other hand, the surface coverage, $\theta$, and inhibition efficiency, $\mathrm{I} \%$, for the investigated compounds, decrease with the increase of the temperature. Figs. 14 and 15 show Arrhenius plots for the corrosion rate, $\mathrm{R}_{\mathrm{w}}$, in pure acid and in the presence of $1 \times 10^{-3} \mathrm{M}$ of the inhibitors, respectively. The values of the apparent activation energy, $\mathrm{E}_{\mathrm{a}}$, could be determined from equation (12):

$$
R_{w}=K \exp \left(\frac{-E_{a}}{R T}\right)
$$

The calculated values of apparent activation energy, $\mathrm{E}_{\mathrm{a}}$, are: $35,64.9,54.7,57.9$ and $72.92 \mathrm{~kJ} / \mathrm{mol}$ for the pure acid and in the presence of the organic compounds (p, $2 \mathrm{mp}, 3 \mathrm{mp}, 4 \mathrm{mp}$ ), respectively.

Ideally, a corrosion inhibitor is a substance that increases the activation energy of the corrosion process. This is clear from the values of $E_{a}$ in pure acid and in the presence of the inhibitors. This indicates that the energy barrier for the corrosion reaction increases in the presence of these additives. This means that by addition of the inhibitor in the acid solution, the corrosion reaction will be further pushed to surface sites that are characterized by higher values of $\mathrm{E}_{\mathrm{a}}$, indicating that the alloy corrosion occurs at the uncovered part of the surface. The value of $E_{a}$ for the investigated inhibitors increases according to the order: $2 \mathrm{mp}<3 \mathrm{mp}<\mathrm{p}<4$ $\mathrm{mp}$. This order is the same of the inhibition efficiency, I\%, of the investigated compounds. 


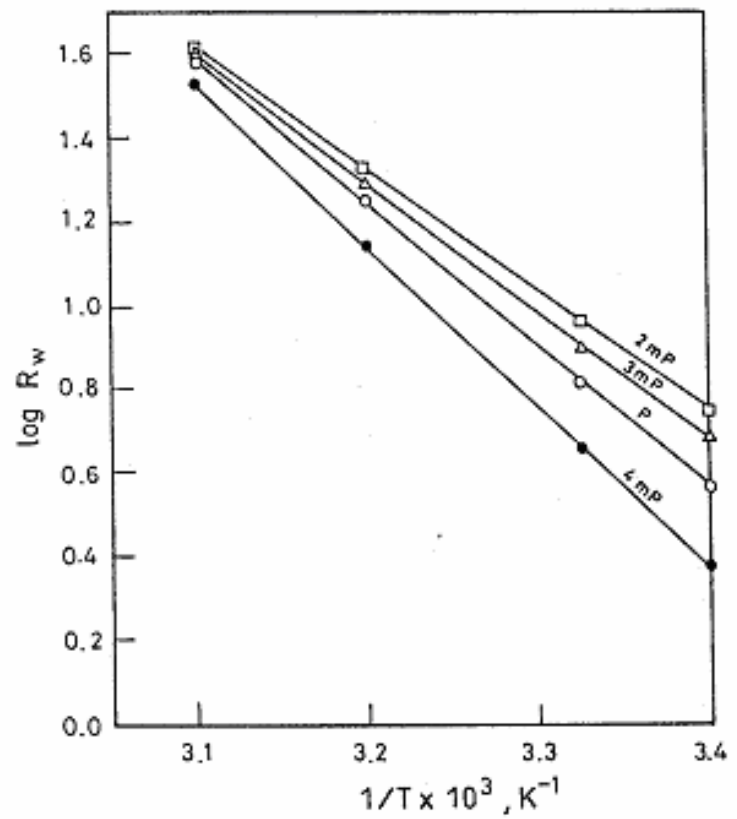

Figure 15. Arrhenius plots of $\log \mathrm{R}_{\mathrm{w}}$ against $1 /$ Tin $0.5 \mathrm{M} \mathrm{HCl}$ containing $1 \times 10^{-3} \mathrm{M}$ of each compound.

The possibility of correlating the structural characteristics with inhibition efficiency of organic substances can be justified by the assumption that the metal-inhibitor interactions are based on chemisorption. The electron density on the adsorption center of organic compound is then obviously important. It is possible to assume a bond of the Lewis acid-base type, generally with the inhibitor as the electron donor and the metal as the electron acceptor. The strength of this bond depends on the characteristics of both the adsorbent and adsorbated. The obtained results show that the presence of methyl group $\left(-\mathrm{CH}_{3}\right)$ in 4-position of pyridine increases the inhibition efficiency of the organic compound. On the other hand, the presence of the methyl group $\left(-\mathrm{CH}_{3}\right)$ in 2 or 3position decreases the inhibition efficiency of the investigated compound. As above mentioned the efficiency of the organic compounds increases according to the order: $2 \mathrm{mp}<3 \mathrm{mp}<\mathrm{p}<4 \mathrm{mp}$. It can be mentioned that the center of adsorption of these compounds may be $\mathrm{N}$-atom. The introduction of the methyl group in 4-position of heterocyclic ring increases the electron density on the center of adsorption ( $\mathrm{N}$-atom) as a result of the electron repelling character of the group. This state leads to the increase of the inhibition efficiency of the compound $4 \mathrm{mp}$, which becomes better than the parent compound $\mathrm{p}$. On the other hand, the introduction of methyl group in 2 or 3-position gives rise to a steric effect which in turn decreases the inhibition efficiency of the compounds $2 \mathrm{mp}$ and $3 \mathrm{mp}$. Also, it can be stated that the steric effect of 3-position is less than that of 2-position. This leads to the above mentioned order of the inhibition efficiency. 
Table 19. Data of weight loss measurements for the alloy in $0.5 \mathrm{M} \mathrm{HCl}$ at different temperatures.

\begin{tabular}{ccccc}
\hline Temp. $/{ }^{\circ} \mathrm{C}$ & $\mathrm{K}$ & $1 / \mathrm{T}$ & $\mathrm{R}_{\mathrm{W}} /\left(\mathrm{mg} / \mathrm{cm}^{2} / \mathrm{h}\right)$ & $\log \mathrm{R}_{\mathrm{w}}$ \\
\hline 20 & 293 & $3.41 \times 10^{-3}$ & 20 & 1.3 \\
30 & 303 & $3.30 \times 10^{-3}$ & 30 & 1.477 \\
40 & 313 & $3.195 \times 10^{-3}$ & 45 & 1.65 \\
50 & 323 & $3.096 \times 10^{-3}$ & 70 & 1.845 \\
\hline
\end{tabular}

Table 20. Data of weight loss measurements for the alloy in $0.5 \mathrm{M} \mathrm{HCl}$ in the presence of $1 \times 10^{-3} \mathrm{M} p$ at different temperatures.

\begin{tabular}{cccc}
\hline Temp. $/{ }^{\circ} \mathrm{C}$ & $\mathrm{R}_{\mathrm{W}} /\left(\mathrm{mg} / \mathrm{cm}^{2} / \mathrm{h}\right)$ & $\theta$ & $\mathrm{I} \%$ \\
\hline 20 & 3.6 & 0.82 & 82 \\
30 & 6.35 & 0.788 & 78.8 \\
40 & 17.8 & 0.604 & 60.4 \\
50 & 37.8 & 0.46 & 46 \\
\hline
\end{tabular}

Table 21. Data of weight loss measurements for the alloy in $0.5 \mathrm{M} \mathrm{HCl}$ in the presence of $1 \times 10^{-3} \mathrm{M} 2 \mathrm{mp}$ at different temperatures.

\begin{tabular}{cccc}
\hline Temp. $/{ }^{\circ} \mathrm{C}$ & $\mathrm{R}_{\mathrm{W}} /\left(\mathrm{mg} / \mathrm{cm}^{2} / \mathrm{h}\right)$ & $\theta$ & $\mathrm{I} \%$ \\
\hline 20 & 5.6 & 0.72 & 72 \\
30 & 9.3 & 0.69 & 69 \\
40 & 21.3 & 0.522 & 52.2 \\
50 & 40.6 & 0.42 & 42 \\
\hline
\end{tabular}

Table 22. Data of weight loss measurements for the alloy in $0.5 \mathrm{M} \mathrm{HCl}$ in the presence of $1 \times 10^{-3} \mathrm{M} 3 \mathrm{mp}$ at different temperatures.

\begin{tabular}{cccc}
\hline Temp. $/{ }^{\circ} \mathrm{C}$ & $\mathrm{R}_{\mathrm{W}} /\left(\mathrm{mg} / \mathrm{cm}^{2} / \mathrm{h}\right)$ & $\theta$ & $\mathrm{I} \%$ \\
\hline 20 & 4.8 & 0.76 & 76 \\
30 & 8.0 & 0.733 & 73.3 \\
40 & 19.5 & 0.567 & 56.7 \\
50 & 39.2 & 0.44 & 44 \\
\hline
\end{tabular}

Table 23. Data of weight loss measurements for the alloy in $0.5 \mathrm{M} \mathrm{HCl}$ in the presence of $1 \times 10^{-3} \mathrm{M} 4 \mathrm{mp}$ at different temperatures.

\begin{tabular}{cccc}
\hline Temp. $/{ }^{\circ} \mathrm{C}$ & $\mathrm{R}_{\mathrm{W}} /\left(\mathrm{mg} / \mathrm{cm}^{2} / \mathrm{h}\right)$ & $\theta$ & $\mathrm{I} \%$ \\
\hline 20 & 2.4 & 0.88 & 88 \\
30 & 4.5 & 0.85 & 85 \\
40 & 14.2 & 0.684 & 68.4 \\
50 & 33.6 & 0.52 & 52 \\
\hline
\end{tabular}




\section{Conclusions}

1. The corrosion rate of the $\mathrm{Zn}-\mathrm{Al}-\mathrm{Cu}$ alloy in $\mathrm{HCl}$ solutions is higher than that of $\mathrm{Al}$ or $\mathrm{Zn}$.

2. The corrosion rate of the alloy greatly increases with the increase of acid concentration.

3. Pyridine and its derivatives have high inhibition effect on the corrosion of the alloy in $0.5 \mathrm{M} \mathrm{HCl}$ solution and their effect increases according to the order: $2 \mathrm{mp}<3 \mathrm{mp}<\mathrm{p}<4 \mathrm{mp}$.

4. The investigated inhibitors act as a mixed inhibitor.

5. The inhibitory effect of these compounds resulted from the interaction between the inhibitor molecule, via $\mathrm{N}$-atom, and the metallic surface, that decreased the active centers.

6. The adsorption of the investigated compounds onto the alloy surface obeyed Frumkin's adsorption isotherms.

7. The inhibition efficiency of the investigated compounds decreased with the increase of temperature. The addition of these compounds to the acid solution increased the values of activation energy of corrosion. The order of this increase was the same as that of inhibition efficiency.

8. There is a good agreement between the results obtained by different techniques.

\section{References}

1. A.K. Neufeld, I.S. Cole, Proceeding - Electrochemical Society 2000-25 (2001) 444-452.

2. I.S. Cole, A.K. Neufeld, S.A. Furman, W.J. Miao, Proceeding Electrochemical 2000-23 (2001) 284-294.

3. K. Haruhiko, Y. Hayami, A. Masani, Bosei Konri 45-3 (2001) 87-91.

4. S.F.L. Mertens, E. Temmerman, Corros. Sci. 43-1 (2001) 69-84 (pub. 2000).

5. J. Tanaka, T. Tamura, T. Narita, Hyomen Gijutsu 51-12 (2000) 1224-1228.

6. A.R. Moreira, Z. Panossian, J.R. Carvalho, I. Carlos da Silva, EBRATS 10th, Sao Paulo, Brazil, May 22-25, 2000; 617 (2000).

7. Y. Li, Xu-Jun Wei, Fa-lun Feng, Zhongguo Youse Jinshu Xuebao 11-2 (2001) 248-252.

8. L. Haufei, Z.D. Jiashen, Mater.-Perform. 40-5 (2001) 32-36.

9. J. Maki, S. Yamaguchi, T. Isaki, M. Kurosaki, Jpn. Kokai Takkyo Koho 316 (2001) 791.

10. J. Zhao, Proc. Corros. Prev. 612-617 (2000).

11. St. Gyurov, N. Guidikova, A. Ilinkina, Takh. Misul 33-3 (1996) 86-91 (Bulg.).

12. S. Nizoguchi, Y. Nishiki, Yosha Gijutsu 16-3 (1997) 34-40 (Jap.).

13. T. Tsuru, S. Haruyama, Boshoku Gijutsu, J. Japan Soc., Corros. Engng. 27 (1978) 573.

14. A.B. Brown, J. Electrochem. Soc. 134 (1987) 2506. 
15. G.A. El-Mahdy, S.S. Mahmoud, Corros. Sci. 51 (1995) 436.

16. A.G. GadAllah, M.M. Hefny, S.A. Salih, M.S. El-Basiouny, Corros. Sci. 45 (1989) 574.

17. M.S. Abdel-Aal, Z.A. Ahmed, M.S. Hassan, J. Appl. Electrochem. 22 (1992) 1104.

18. S.G. Aziz, A.Y. Obaid, A.O. Alyoubi, A.A. Abdel-Fattah, Corros. Preven. Control 44 (1997) 179.

19. A. Frignani, G. Trabanelli, F. Zucchi, M. Zucchini, Proc. 5th Europ. Symp. Corros. Inhibitors, Ferrara, Italy, 1185 (1980).

20. E. Khamis, Corrosion 46-6 (1990) 476.

21. B. Hammouti, A. Aouniti, M. Taleb, M. Brighli, S. Kertit, Corros. Sci. 51 (1995) 411.

22. F. Bentiss, M. Traisnel, M. Lagrenee, Br. Corros. J. 35 (2000) 315.

23. B. Abd-ElNabey, N. Khalil, A. Mohamed, Surface Technology 24 (1985) 383.

24. S. Kertit, B. Hammouti, Appl. Surf. Sci. 93 (1996) 59. 